\title{
THE DEVELOPMENT OF CLASS-BASED ASSESSMENT TO MEASURE STUDENT CRITICAL THINKING ON CHEMICAL LEARNING USING THE CONTEXTUAL TEACHING AND LEARNING MODEL
}

\author{
Nahadi \\ Department of Chemistry Education, FPMIPA, Universitas Pendidikan Indonesia \\ E-mail: nahadi@upi.edu \\ Wiwi Siswaningsih \\ Department of Chemistry Education, FPMIPA, Universitas Pendidikan Indonesia \\ E-mail: wiwi@upi.edu \\ Sarah Fadilla \\ Department of Chemistry Education, FPMIPA, Universitas Pendidikan Indonesia \\ E-mail: fadilla@upi.edu
}

\begin{abstract}
APA Citation: Nahadi, N., Siswaningsih, W., \& Fadilla, S. (2018). The development of class-based assessment to measure student critical thinking on chemical learning using the contextual teaching and learning model. Indonesian Journal of Learning and Instruction, 1(1), 13-20.
\end{abstract}

\begin{abstract}
The purpose of this study was to obtain class-based assessment instrument that can measure the critical thinking skills of students in learning chemistry using a model of contextual teaching and learning. The research method used is a research and development (R \& D) with the design of the study one group pretest-posttest. The study was conducted on 34 students of class $\mathrm{X}$ at one of the public high schools in Bandung with the object of research in the form of assessment tools consisting of critical thinking skills test consisting of 15 multiple choice questions grounded, 3 pieces of essays, and 6 pieces of matter worksheets, observation sheet, guidance interviews, and questionnaires . The results showed that the multiple choice questions have reasoned highest validity deduce indicators and consider the results of deduction, low reliability, level of difficulty between easy to difficult, and significant distinguishing features. Essay has the highest validity indicators ask and answer questions with high reliability, moderate difficulty level, and significant distinguishing features. Student Worksheet has the highest validity indicators ask and answer questions with very high reliability, level of difficulty between easy to moderate, and significant distinguishing instrument developed to measure students' critical thinking skills about the views of validity, with the highest validity of multiple choice questions grounded is number 4 and 13, the highest validity essay is number $1 \mathrm{a}$ and $1 \mathrm{~b}$, and the highest validity LKS numbers 1,2, and 3. Contextual teaching and learning can be supportive in improving students' critical thinking skills that can be seen from curiousity stages through observation sheet.
\end{abstract}

Keywords: class-based assessment; critical thinking skills; contextual.

\section{INTRODUCTION}

Assessment is one of the important components in learning. Firman (2000) states that assessment as a process of determining the necessary information, collecting, and using that information as a consideration before making decisions. Assessment is an activity of collecting information as evidence to serve as the basis for determining the occurrence of change and the degree of change that has been achieved as a learning result of learners (Komalasari, 2010).

Ideally, an assessment is capable of measuring the whole domain, whether cognitive, affective, or psychomotor. The implementation of KTSP demands changes in learning and assessment that lead to the achievement of competencies. The competence in the curriculum refers to the ability that can be done by learners which 
includes knowledge, skills and behavior. Hence, assessment should refer to learners' basic competence (Haryono, 2009).

Generally, assessments conducted in many schools tend to focus on cognitive assessment. The existence of the National Exam (UN) has formed an opinion in the community and among learners to pass the UN with high scores. Parents do not want their children not to pass the UN simply because they fail in one of the UN's subjects. This creates a tendency for the learner's interest to study only the UN subjects. This condition also affects the chemistry lesson as one of UN's subjects. Learners tend to prioritize the mastery of chemical knowledge without being able to apply the knowledge they have gained in everyday life.

The results of Dewey's research (Rosyidah, 2005) suggest learners will learn better if what is learned is related to what has been known and with activities or events that will occur around them. This learning emphasizes on high order thinking, transferring of knowledge, collecting and analyzing data, and solving specific problems both individually and in groups.

Contextual Teaching and Learning (CTL) is a learning concept that can help teachers relate between the material they teach and the real-world situations of learners and encourage them to make connections between their knowledge and its application in their lives as family members and the community. Through CTL, learners do not only have knowledge, but they can also develop attitudes and skills that can be applied in life (Susilana, 2006). CTL also teaches steps that can be used in critical thinking and gives an opportunity to use this higher-order thinking skills in the real world (Johnson, 2007). Contextual Teaching and Learning (CTL) can help in developing an authentic assessment process or classroombased assessment that captures the potential of learners in full, comprehensive, and sustainable learning.
Class-Based Assessment (PBK) as one of the characteristics of CTL can provide balance to the three domains, namely cognitive, affective, and psychomotor by using various forms and models of assessment conducted systematically, thoroughly, and continuously. PBK is expected to be useful to obtain data and information as a whole about learners' achievement and their learning progress. PBK also intends to give rewards and justice to all learners (Arifin, 2009).

Petroleum is one of the materials taught in senior high school class $\mathrm{X}$ of the second semester. This material is often ignored or even not learned and assigned students to read it at home because it is considered only as a memorization. In fact, this material is very important because it is very relevant to the learners' everyday life. Learners need to know more about this material so they can apply it in life. This is in line with Atina (2008) who states the difficulty mostly experienced by learners in the petroleum material is to provide solutions concerning the impact of petroleum burning and the impact of fuel combustion.

Based on the description, the researcher is interested in conducting a research on the development of class-based assessment to measure students' critical thinking skills in petroleum learning using contextual teaching learning model.

\section{METHOD}

The research method used is research and development (Sukmadinata, 2010) which is limited to product development with one group pretest-postest research design. This study was conducted to 34 students of class $\mathrm{X}$ in one of the State Senior High School in Bandung with the object of research in the form of class-based assessment tools, namely critical thinking skills test, observation sheets, worksheets, questionnaires, and interviews. The research flow can be seen in figure 1 . 


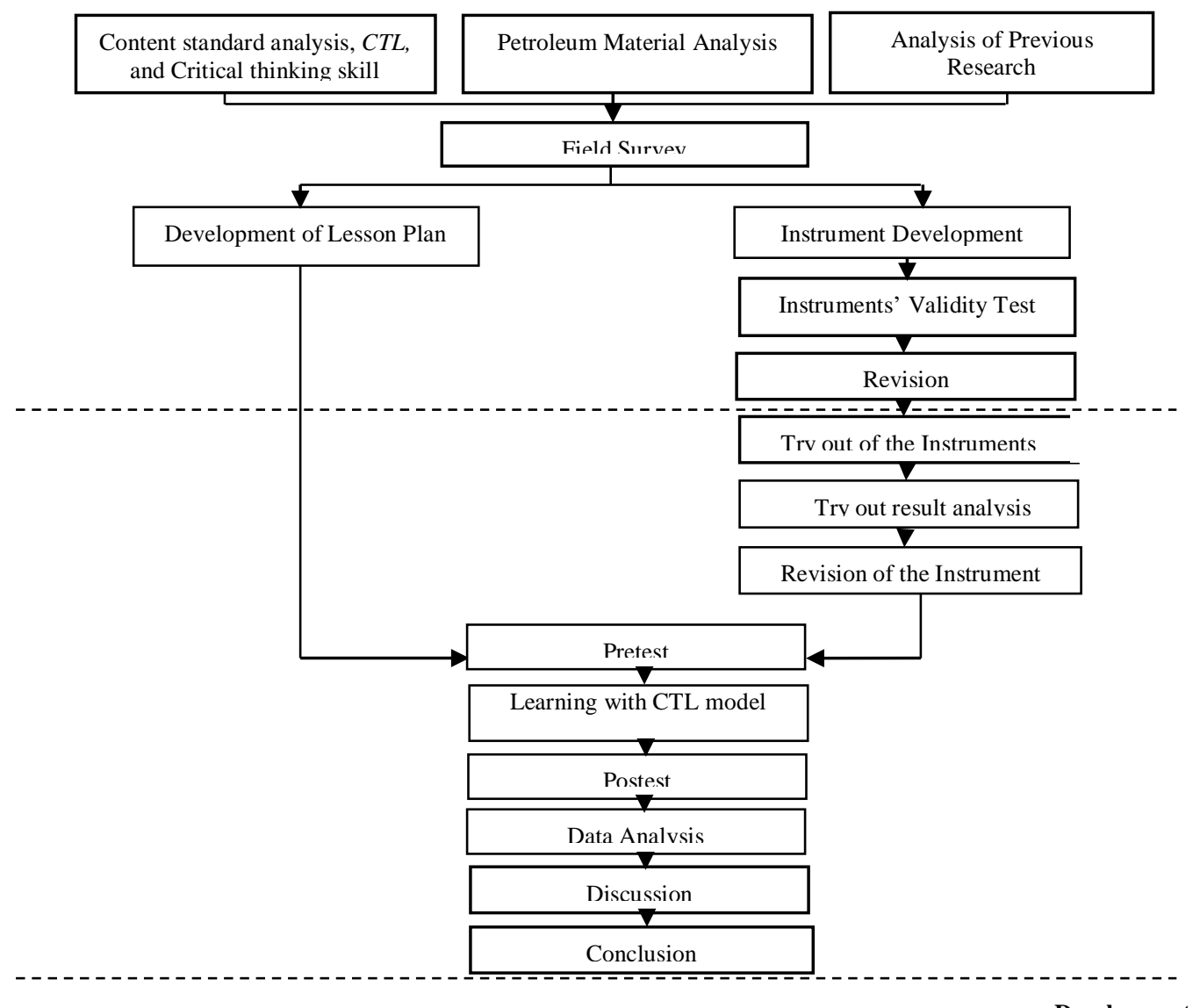

Figure 1. Research flow

\section{RESULTS AND DISCUSSION}

The development of class-based assessment instruments is conducted in accordance with the steps of Research and Development (R \& D) developed by Sukmadinata (2010). There are three stages of $\mathrm{R} \& \mathrm{D}$, namely preliminary study, product development, and product testing. In this research, the step is done until product development. The research instruments used to create class-based assessment instrument is in the form of validaty test of critical thinking skill, students' worksheet, observation sheet, questionnaire, and interview guideline.

The creation of a class-based assessment instrument begins with a preliminary study to analyze SK and KD, critical thinking skills, contextual teaching and learning, petroleum materials, and previous research. After that, field survey was done. The results from field surveys, as Halimah, et al. (2007) states teachers still do not understand well about class-based assessment systems. Atina (2008) states the difficulty mostly experienced by learners in the petroleum material is to provide solutions concerning the impact of petroleum burning and the impact of fuel combustion. From the results of interviews with high school chemistry teachers where the research was done, it was found that teachers get difficulties in assessing student attitudes in detail, their assessments tend to be subjective, and done globally every semester or mid semester. In addition, the teacher said that there is no effective method to improve students' critical thinking skills. This needs to be synchronized with the character of the lesson.

The next step is to arrange the instrument grid and content validity test by inviting judgment from expert groups in the measured field. This is done so that the test is able to measure the things that represent the entire content of the lesson material that will be measured. As stated by Firman (2000), the validity of the content is the validity of a measuring instrument in terms of the content of the lesson material covered by the measuring instrument. The second step is product development. In this step, class-based assessment is tried out. The instruments used for this try out step are written test and 
Nahadi, Wiwi Siswaningsih, \& Sarah Fadilla

The development of class-based assessment to measure student critical thinking on chemical learning using the contextual teaching and learning model

students' worksheet. The results of this try out results of the try out test can be seen in Table test are used to determine the level of validity, $1-4$.

reliability, and difficulty of the test. The

Table 1. The results of try out test

\begin{tabular}{|c|c|c|c|c|}
\hline & Validity & Reliability & $\begin{array}{l}\text { Level of } \\
\text { Difficulty }\end{array}$ & $\begin{array}{c}\text { Distinguishing } \\
\text { Potency }\end{array}$ \\
\hline $\begin{array}{l}\text { Multiple } \\
\text { Choice }\end{array}$ & $\begin{array}{l}\text { The highest validity lies on } \\
\text { the indicators of deducting } \\
\text { and considering the results } \\
\text { of deduction }\end{array}$ & 0.21 (Low) & $\begin{array}{l}\text {-Easy: } \\
\text { 1,2,3,5,7,8,9,1 } \\
\text { 1,12 } \\
\text {-Medium: } \\
\text { 4,10,15 } \\
\text {-Difficult: } \\
6,13,14\end{array}$ & $\begin{array}{l}\text {-accepted: } \\
4,6,9,13,15 \\
\text {-revised: } \\
11,12,13 \\
\text {-rejected: } \\
1,2,3,5,7,8,14\end{array}$ \\
\hline Essay & $\begin{array}{l}\text { The highest validity lies on } \\
\text { the indicator of asking and } \\
\text { responding question. }\end{array}$ & 0.74 (High) & $\begin{array}{l}\text { - Easy:- } \\
\text { - Medium: } \\
\text { 1a, 1b, 1c, 2,3 } \\
\text {-Difficult: }\end{array}$ & $\begin{array}{l}\text { - No. 1a \& } 3 \\
\text { significant } \\
\text { - No } 1 \mathrm{~b}, 1 \mathrm{c}, 2 \text { do } \\
\text { not significant }\end{array}$ \\
\hline Worksheet & $\begin{array}{l}\text { The highest validity lies on } \\
\text { the indicator of asking and } \\
\text { responding question. }\end{array}$ & $\begin{array}{l}0.89 \text { (Very } \\
\text { High) }\end{array}$ & $\begin{array}{l}\text {-Easy :1 } \\
\text {-Medium: } \\
\text { 2,3,4,5,6 } \\
\text {-Difficult :- }\end{array}$ & $\begin{array}{l}\text {-No. } 1,3,5,6 \\
\text { significant } \\
\text {-No, } 2 \& 4 \text { do not } \\
\text { significant yet }\end{array}$ \\
\hline
\end{tabular}

Table 2. The result of validity test of multiple choice

\begin{tabular}{llrl}
\hline \multicolumn{1}{c}{ No } & \multicolumn{1}{c}{ Critical Thinking Indicators } & $\mathbf{r}_{\mathbf{x y}}$ & Validity Criteria \\
\hline $1,5,10$, & Asking and responding to the questions & 0,4072 & Enough \\
12 & & 0,5994 & Enough \\
6,9 & Analyzing of the arguments & 0,6829 & High \\
4,13 & $\begin{array}{l}\text { Deducting and considering the deduction } \\
\text { result }\end{array}$ & 0,4315 & Enough \\
$2,3,7,8$, & $\begin{array}{l}\text { Creating and determining the result of a } \\
11,14,15\end{array}$ & consideration & \\
\hline
\end{tabular}

Table 3. The result of validity test of essay

\begin{tabular}{llrl}
\hline \multicolumn{1}{c}{ No } & \multicolumn{1}{c}{ Critical Thinking Indicators } & $\mathbf{r}_{\mathbf{x y}}$ & Validity Criteria \\
\hline 1a, 1b & Asking and responding to the questions & 0,8019 & Very High \\
3,2 & Analyzing of the arguments & 0,6500 & High \\
1c & $\begin{array}{l}\text { Creating and determining the result of a } \\
\text { consideration }\end{array}$ & 0,6746 & High \\
\hline
\end{tabular}

Table 4. The result of validity test of worksheet

\begin{tabular}{|c|c|c|c|}
\hline No & Critical Thinking Indicators & $\mathbf{r}_{\mathbf{x y}}$ & Validity Criteria \\
\hline $1,2,3$ & Asking and responding to the questions & 0,6946 & High \\
\hline 4 & $\begin{array}{l}\text { Deducting and considering the deduction } \\
\text { result }\end{array}$ & 0,5533 & Enough \\
\hline 5,6 & $\begin{array}{l}\text { Creating and determining the result of a } \\
\text { consideration }\end{array}$ & 0,5999 & Enough \\
\hline
\end{tabular}

Table 5. The comparison of pre-test and post-test score

\begin{tabular}{lcc}
\hline \multicolumn{1}{c}{ Test } & $\begin{array}{c}\text { The Average of } \\
\text { Pretest Score }\end{array}$ & $\begin{array}{c}\text { The Average of } \\
\text { Posttest Score }\end{array}$ \\
\hline Multiple Choice & 35,95 & 46,34 \\
Essay & 38,05 & 55,33 \\
\hline
\end{tabular}

Table 6. The comparison of pre-test and post-test score of each group

\begin{tabular}{cccc} 
Test & Group & $\begin{array}{c}\text { The Average of } \\
\text { Pretest Score }\end{array}$ & $\begin{array}{c}\text { The Average of } \\
\text { Posttest Score }\end{array}$ \\
\hline
\end{tabular}




\begin{tabular}{clll}
\hline Multiple & High & 35,31 & 46,91 \\
Choice & Medium & 33,73 & 43,27 \\
& Low & 40,49 & 51,11 \\
Essay & High & 41,67 & 60,42 \\
& Medium & 39,45 & 56,25 \\
& Low & 31,94 & 49,31 \\
\hline
\end{tabular}

The data of the application of the instrument developed against the implementation of learning and students' achievement can be seen in Figure 2, 3 and 4 below.

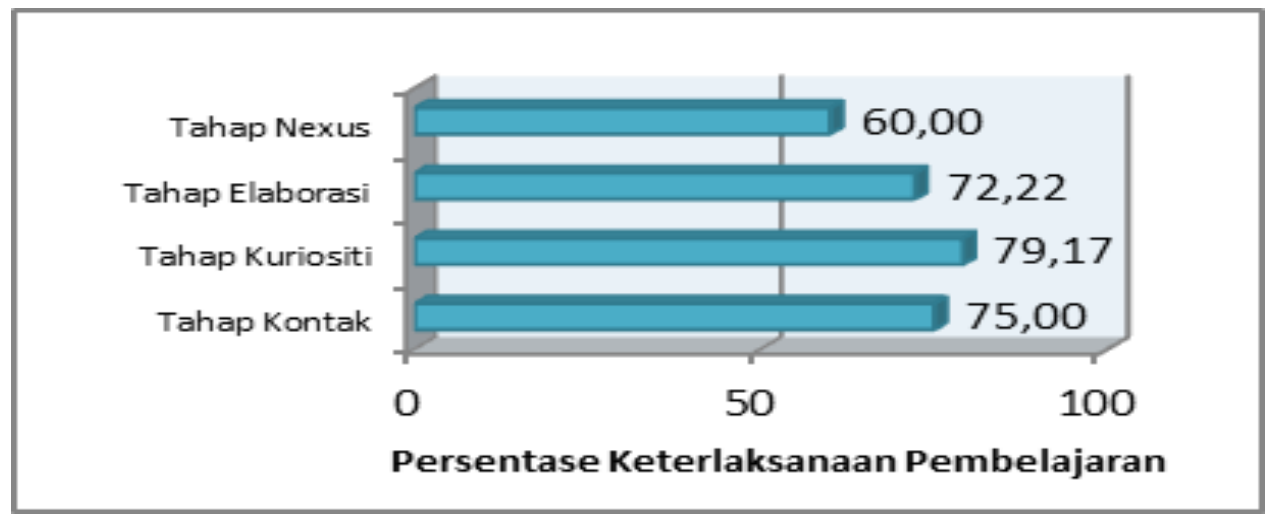

Figure 2. The success of learning process

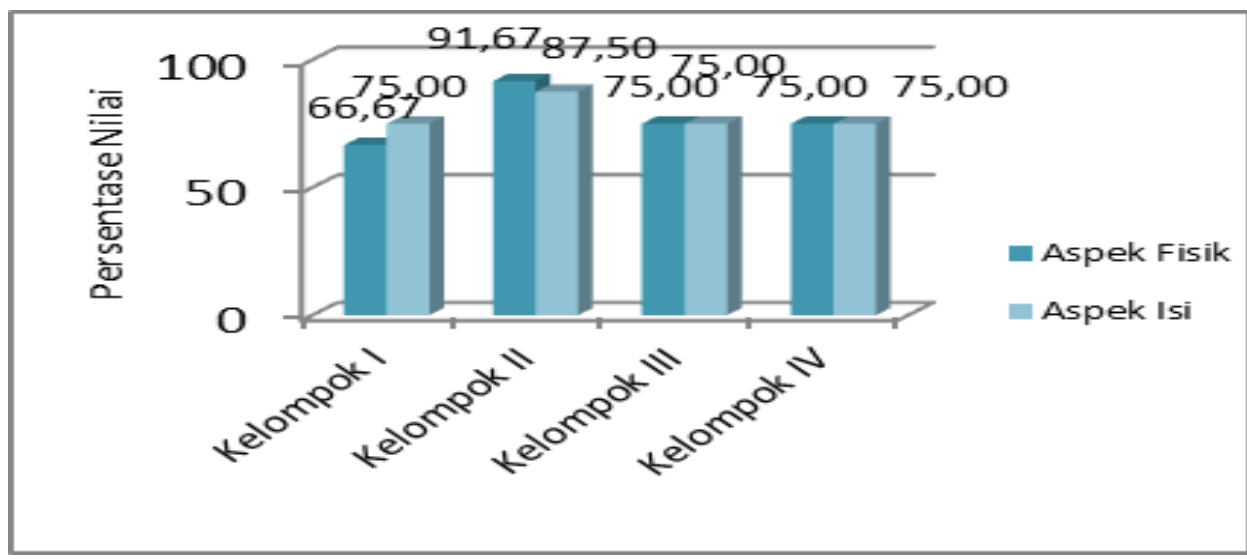

Figure 3. Percentage of poster assessment

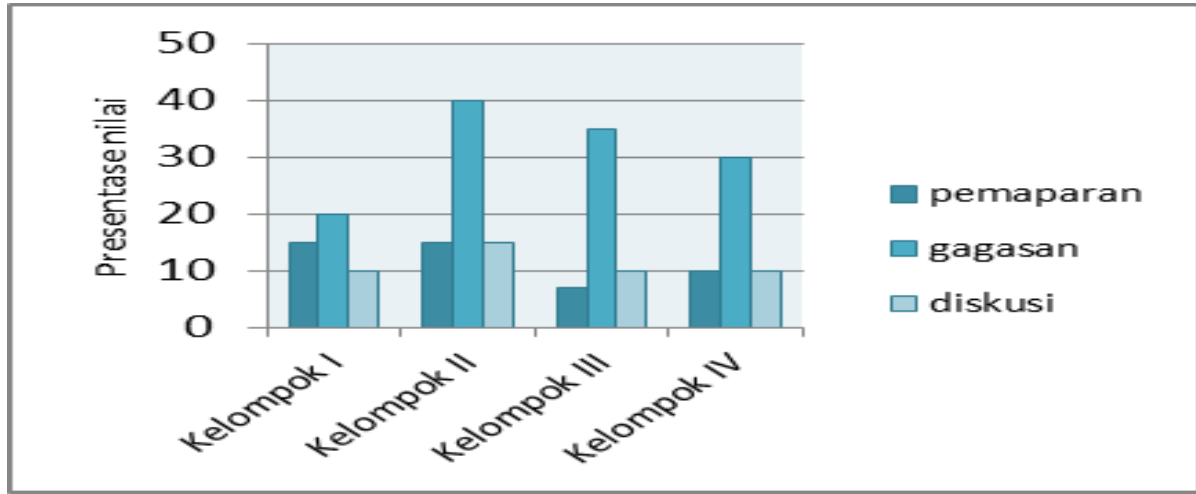

Figure 4. Percentage of learners' achievement

The result of the research indicates that the multiple choice question has the highest validity on the deductive indicator and considering the deduction result, while the essays and worksheet have the highest validity on indicators of asking and responding to the 
questions. When viewed from the value of validity, multiple choice questions, essays, and worksheet can measure what should be measured. Reliability measures the sharpness of an instrument. Multiple-choice questions have low reliability while essays and worksheet have high reliability. The high reliability coefficient is influenced by several factors. Crocker and Algina (Surapranata, 2004) mentioned that the factors include the length of a test, homogeneity of the hemisphere, and the difficulty level of the questions. According to Alen and Yen, and Crocker and Algina (Surapranata, 2004), the level of difficulty has the most dominant role. This is due to the variation of the number of questions that can be answered correctly.

From table 4, there is a question that is rejected because it has a distinguishing potency 0 meaning that this question cannot show any difference in ability between high and low group. This can result from a less conducive class atmosphere. Distinguishing potency of the number 14 marked negative indicates that the lower group can correctly answer the question while the upper group gives a qrong answer. This can happen because of a mistake in understanding the concept in high group students. This also means that many test participants answer correctly on this question because of the guessing factor. Some other questions, such as numbers $10,11,12$, and 14 need to be revised. This is in accordance with the criteria proposed by Surapranata (2004), for questions with a power coefficient differentiating between 0.10 to 0.29 need to be revised. Questions number 4, 6, 9, 13, and 15 have met the criteria of good distinguishing potency.

For the essay, questions number 1a, 1c, and 3 meet the criteria of good distinguishing potency. While number $1 \mathrm{~b}$ and 2 still need to be revised. The differentiation power index of number 2 needs to be revised and question number 4 is rejected. As for worksheet, overall, it has fulfilled a good differentiator in which question number 2 is rejected, number 5 and 6 are revised, and the number 1,3 and 4 are acceptable.

From table 4, the difficulty level of multiple choice questions numbers $1,2,3,5$,
7 , and 8 has a very low level of difficulty according to Arifin (2009). All students, both from high and low groups can answer the questions correctly. So, it can be said that the question is an easy question. Questions number 6,13 , and 14 are in the difficult category with question number 14 have the highest difficulty level. Questions number 4, 10 and 15 are moderate and numbers 9,11 and 12 are easy. This can be because students can guess which answer is considered correct. For essays, all questions have a moderate degree of difficulty as they are at $0.3 \leq p \leq 0.7$. This moderate level of difficulty can be affected by several factors, such as assessment criteria. In the worksheet, question number 1 has a difficulty level of 0.8014 . This shows that about $80 \%$ of students can answer the question with maximum score demands. Questions number 2,3,4,5 and 6 have a moderate degree of difficulty indicating that only about $50 \%$ of students are able to answer these questions according to the maximum value demands.

From table 5 and 6 , it can be seen an increase in the average score of students pretest and posttest. This shows that there is an improvement of students' critical thinking skills after experiencing learning by using contextual teaching and learning model, both for high, medium, and low groups. The average achievement of worksheet scores for each group is 51.39 for high group, 48.70 for medium group, and 44.91 for low group. This worksheet grade becomes one of the relevance of an increase in posttest score.

In this study, in addition to the development of cognitive aspects, it is also developed indicators that are then downgraded into affective goals. This affective assessment is seen from the observation sheet, questionnaire, and interview. The observation sheet used consisted of an affective assessment observation sheet related to the learning activity. These learning activities include teaching and learning activities, assigning posters and presentation (Figure 24).

Most students showed an interest in chemistry and chemistry learning, giving a positive response to the evaluation, and most students have been able to demonstrate their 
critical thinking skills. From the results of interviews to students, it was fount that students respond positively to class-based assessments. From this affective assessment, students seen enthusiastic and have a high curiosity in the learning that is indicated by the seriousness in discussing and providing comments on the issues raised.

Contextual teaching and learning can support in improving students' critical thinking skills which can be seen from the curiosity stage through the observation sheet. In this stage, students enthusiastically answer the teacher's questions as well as the issues expressed. In addition, in making poster, students can use their creativity. In the presentation, the students are less able to expose and give opinions even though the ideas presented are good enough.

\section{CONCLUSION}

Based on the results of data analysis and discussion, it is obtained; the development of class-based assessment instruments was carried out in accordance with the Research and Development stage, which is limited to product development. The class-based assessment instrument has the following criteria of test; 1 ) Written test; In a multiple choice, the validity of the factor with the highest criterion is in the indicator to deduce and consider the result of the deduction, and the questioning indicator and answer the question has the lowest validity. The reliability of multiple choice tests is 0.21 (low), the difficulty level between easy to difficult and significant level of distinguishing potency. 2) The essay question has the highest factor validity on the questioning and answering questions and the lowest indicator on analyzing the argument. The reliability of multiple choice tests is 0.78 (high), moderate difficulty level and significant distinguishing potency. 3) Worksheet has the highest validity on the indicator of asking and answering questions and the lowest on the indicators of deducing and considering the results of deduction. Worksheet's reliability is 0.89 (very high), the level of difficulty between easy to moderate and significant distinguishing potency. 4) The developed instrument can measure students' critical thinking skills seen from the validity of the measuring instrument. The highest validity for the multiple choice questions is the numbers 4 and 13 , the highest validity of the essay is the numbers $1 \mathrm{a}$ and $1 \mathrm{~b}$, and the highest validity of worksheet is numbers 1,2 , and $3 ; 5$ ) Contextual teaching and learning can support in improving students' critical thinking skills as it can be seen from curiosity stage through observation sheet.

\section{REFERENCES}

Arifin, Z. (2009). Evaluasi pembelajaran prinsip, teknik, prosedur. Bandung: Remaja Rosdakarya.

Atina, S. (2008). Analisis kesulitan siswa SMA kelas X pada materi pokok minyak bumi dengan menggunakan metode discovery inquiry. Unpublished thesis. Universitas Pendidikan Indonesia.

Firman, H. (2000). Penilaian hasil belajar dalam pengajaran kimia. Bandung: Universitas Pendidikan Indonesia.

Halimah, L., Realin S., \& Ernalis. (2007). Pengembangan model sistem penilaian berbasis kelas dalam pembelajaran bahasa indonesia di sekolah dasar. Retrieved from: http://wahyu021.student.umm.ac.id/files/20 10/02/Lely-Halimah-FIP-Hiber.doc.

Haryono, A. (2009). Authentic assessment dan pembelajaran inovatif dalam pengembangan kemampuan siswa Retrieved from: http://fe.um.ac.id/wpcontent/uploads/2010/03/Assessment-PAgung.pdf.

Johnson, E. B. (2007). Contextual teaching and learning: Menjadikan kegiatan belajarmengajar mengasyikan dan bermakna. Bandung: Mizan Learning Center.

Komalasari, K. (2010). Pembelajaran kontekstual konsep dan aplikasi. Bandung : Refika Aditama.

Rosyidah. (2005). Pengembangan KBK melalui pembelajaran kontekstual. Retrieved from: http://re-searchengines.com/art05-96.html.

Sukmadinata, N. S. (2010). Metode penelitian pendidikan. Bandung: Remaja Rosdakarya.

Surapranata, S. (2004). Analisis validitas, reliabilitas, dan interpretasi hasil tes implementasi kurikulum 2004. Bandung: Remaja Rosdakarya.

Susilana, R. (2006). Kurikulum dan pembelajaran. Bandung: Jurusan Kurikulum dan Teknologi Fakultas Ilmu Pendidikan Universitas Pendidikan Indonesia. 
Nahadi, Wiwi Siswaningsih, \& Sarah Fadilla

The development of class-based assessment to measure student critical thinking on chemical learning using the contextual teaching and learning model 